\title{
Monitoring of Organochlorine Pesticide Residues in Groundwater Samples from Sana'a City (Yemen) by Gas Chromatography Using Solid Phase Extraction Method
}

Awadh, G. A. M. * and M. A. A. Hashim

Plant Protection Dept., Fac. of Agric., Sana'a Univ., Sana'a, Yemen

* Corresponding author. Tel.: +967-777133934; fax: +967-1-248141.

E-mail address: jalalawadh@hotmail.com.

\section{ABSTRACT}

Residue values of organochlorine pesticides (OCPs) in groundwater samples from Sana'a, the capital of Yemen, are reported. A total of 60 water samples from 10 main sampling sites in Sana' City were extracted with the extraction solvents (Dichloromethane : hexane; 3:1) and Solid Phase Extraction (SPE) method was used for the extraction of residues in water sample. The analysis of the 18 OCPs $(4,4-$ DDD, 4,4-DDE, 4,4-DDT, a-endosulfan, a- $\mathrm{HCH}$, aldrin, b-endosulfan, b- $\mathrm{HCH}$, d-HCH, dieldrin, endosulfan sulfate, endrin, endrin aldehyde, endrin ketone, heptachlor, heptachlor epoxide, lindane and methoxychlor) was carried out by capillary gas chromatography equipped with an electron capture detector $\left({ }^{63} \mathrm{Ni}\right)$, split/splitless mode. Three residues of 18 targeted OCPs were found in 3 samples only. Among the various pesticides analyzed only, aldrin $(0.0002 \mu \mathrm{g} / \mathrm{l})$, dieldrin $(0.0007 \mu \mathrm{g} / \mathrm{l})$ and 4,4-DDT $(0.0005 \mu \mathrm{g} / \mathrm{l}) \mathrm{were}$ found in the groundwater samples. For all compounds examined, all concentration levels of residues were found to be within WHO and European Economic Commission Standards (EEC) for drinking water quality.

Keywords: Organochlorine, pesticide residues, groundwater, Sana'a gas-chromatography, solid phase extraction

\section{INTRODUCTION}

Organochlorine pesticides (OCPs) have an extended history of widespread use worldwide. In spite of their proscription and restrictions, many countries are yet using them for various intentions (public health, agriculture), because of the low cost, ease of use, versatility in controlling various insects (Afful et al., 2010). Yemen still utilizes considerable quantities of some organochlorine pesticides, such as DDT, HCB, dieldrin, heptachlor and polychlorinated biphenyls (PCBs), Therefore, they were generally found in shore sediments and marine organisms in the Gulf of Aden coast in trace quantities (DouAbul and Al-Shwafi., 2000). OCPs are among the oldest agrochemicals introduced to control insect pests; they first introduced in the 1940s, and were used extensively until most of them were banned worldwide in the 1970s and 1980s due to their health risks. According to the pesticides manual for the Republic of Yemen, the Yemeni government has banned use of most of persistent OCPs (aldrin, chlordane, dieldrin, endrin, heptachlor, mirex, toxaphene and DDT) since 1990. However, it is believed that smuggling of OCPs still taken place (Ministry of Water and Environment MWE 2003). Organochlorine pesticides are very persistence liposoluble compounds and are capable of bio-accumulating in the fatty parts of biological beings such as breast milk, blood and fatty tissues via the food chains (William et al., 2008). Several studies have indicated the presence of OCPs in water (David et al., 2011; Farshid et al., 2011 and Narasimha et al., 2012), human breast milk (Ennacer et al., 2008 and Okonkwo et al., 1999), soil (Getenga et al., 2004), foodstuffs (Ahmad et al., 2013; Hajslova and Zrostlikova., 2003 and Qin et al., 2011), wildlife (Tanabe et al., 1993) sediments (Fatoki and Awofolu., 2003 and Safina et al., 2011), air (Aydin and Yurdin., 1999), fish (Farshid et al., 2012), serum (William et al., 2008) and in mussels (Prudente et al., 1999). Many of these OCPs and their metabolites have been involved in a wide range of toxic and adverse human and environmental effects including reproduction and birth defects (Hileman, 1994; Edwards, 1987 and Bouman, 2004), immune system malfunction (Kolpin et al., 1998), endocrine disruptions (Adeyemi et al., 2008 and Izelyamu et al., 2007), testicular tumors and lower sperm counts in humans (Davies and Barlow., 1995; Cocco et al., 1997), human breast and liver cancers (Garabrant et al., 1992), altering the metabolism of xenobiotics and steroid hormones (Colborn and Smolen., 1996). OCPs have also been linked to chronic convulsions (Belta et al., 2006), Parkinsons diseases (Fleming et al., 1994). Information of OCPs in sources of drinking water from Sana'a City is limited, no single research paper was found to describe the situation of groundwater contamination by OPCs, this study describe the organochlorine pesticide result in groundwater in Sana'a City. The objective of this study was to evaluate the spectrum of organochlorine pesticides residues in groundwater samples of Sana'a City by solid phase extraction method and analysis with GC-ECD.

\section{MATERIALS AND METHODS}

\section{1- Chemicals and reagents}

OCPs Certified Reference Material (4,4-DDD, 4,4DDE, 4,4-DDT, a-endosulfan, a-HCH, aldrin, b-endosulfan, b- $\mathrm{HCH}$, d-HCH, dieldrin, endosulfan sulfate, endrin, endrin aldehyde, endrin ketone, heptachlor, heptachlor epoxide, lindane and methoxychlor) were purchased from SigmaAldrich (Germany). Stock solutions $(1000 \mu \mathrm{g} / \mathrm{ml})$ were prepared by dissolving the pesticide standards in a mixture of toluene and n-hexane in the ratio (1:1) and a fresh working solution containing a mixture of each analyte was prepared by stepwise dilution of the stock solution in nhexane according to the standard practices. Organic solvents (Dichloromethane, Ethylacetate, Methanol, Toluene \&, nHexane) were of pesticide residue analysis and were obtained from Merck (Darmstadt, Germany). Solid Phase Extraction (SPE) cartridges were obtained from International Sorbent Technology.

\section{2- Study area and sampling}

The sampling sites were composed of ten sources of drinking water wells in Sana'a City, a total of 60 water samples from 10 main sampling sites were collected. After collection of the water samples, the water sample was filtered through watt man filter paper and analyzed by validated method. All the water samples were collected in high purity glass bottles and immediately transported to the 
laboratory. The samples were stored at $+4^{\circ} \mathrm{C}$ and extraction of the OCPs was performed within $48 \mathrm{~h}$. Global positioning system was used to identify the location of collected samples (Table 1).

Table 1. Name and location of collected samples

\begin{tabular}{lccc}
\hline & \multirow{2}{*}{ Site } & \multicolumn{2}{c}{ Coordinate } \\
\cline { 3 - 4 } & & longitude & Latitude \\
\hline 1. & Al-Saleh mosque & $15^{\circ} 19^{\prime} 18.69^{\prime \prime} \mathrm{N}$ & $44^{\circ} 12^{\prime} 26.01^{\prime \prime} \mathrm{E}$ \\
2. & Sana'a University & $15^{\circ} 21^{\prime} 58.91^{\prime \prime} \mathrm{N}$ & $44^{\circ} 10^{\prime} 57.99^{\prime \prime} \mathrm{E}$ \\
3. & Maeen district & $15^{\circ} 22^{\prime} 10.19^{\prime \prime} \mathrm{N}$ & $44^{\circ} 11^{\prime} 06.50^{\prime \prime} \mathrm{E}$ \\
4. & Mathbah & $15^{\circ} 23^{\prime} 01.27^{\prime \prime} \mathrm{N}$ & $44^{\circ} 10^{\prime} 14.33^{\prime \prime} \mathrm{E}$ \\
5. & Al-andulos zoon & $15^{\circ} 22^{\prime} 41.89^{\prime \prime} \mathrm{N}$ & $44^{\circ} 10^{\prime} 30.02^{\prime \prime} \mathrm{E}$ \\
6. & Sawan & $15^{\circ} 22^{\prime} 49.04^{\prime \prime} \mathrm{N}$ & $44^{\circ} 14^{\prime} 19.45^{\prime \prime} \mathrm{E}$ \\
7. & Al-hasabah & $15^{\circ} 23^{\prime} 03.48^{\prime \prime} \mathrm{N}$ & $44^{\circ} 12^{\prime} 47.76^{\prime \prime} \mathrm{E}$ \\
8. & Fifty street & $15^{\circ} 21^{\prime} 41.28^{\prime \prime} \mathrm{N}$ & $44^{\circ} 09^{\prime} 19.78^{\prime \prime} \mathrm{E}$ \\
9. & Al-asbahi & $15^{\circ} 17^{\prime} 45.15^{\prime \prime N}$ & $44^{\circ} 13^{\prime} 56.06^{\prime \prime} \mathrm{E}$ \\
10. & Bani-huat & $15^{\circ} 28^{\prime} 27.77^{\prime \prime} \mathrm{N}$ & $44^{\circ} 13^{\prime} 57.73^{\prime \prime} \mathrm{E}$ \\
\hline
\end{tabular}

\section{3- Sample preparation}

The extraction procedure, recovery and quality control was completed as described by (Ashok and Aman., 2013): Solid Phase Extraction (SPE) was used for the extraction of organochlorine pesticide residues in water sample. The collected water samples were pre-filtered through a $0.45 \mu \mathrm{m}$ nylon filter (Wattman) to remove particulate matter and were acidified with hydrochloric acid $(6 \mathrm{~N})$ to $\mathrm{pH} 2.5$. Methanol modifier $(10 \mathrm{~mL})$ was added to water sample for better extraction. SPE using pre-packed reversed phase octadecyl (C-18 bonded silica) contained in cartridges was used for sample preparation. Prior to the extraction, the $\mathrm{C}-18$ bonded phase, which contains $500 \mathrm{mg}$ of bonded phase, was optimized with $5 \mathrm{~mL}$ of ethylacetate, 5 $\mathrm{mL}$ of dichloromethane, $10 \mathrm{~mL}$ of methanol and $10 \mathrm{~mL}$ of organic free water before use. The sample was mixed well and allowed to percolate through the cartridges with flow rate of $10-15 \mathrm{~mL} / \mathrm{min}$ under vacuum. After sample extraction, suction continued for $15 \mathrm{~min}$ to dry the packing material and pesticides trapped in the $\mathrm{C}-18$ bonded phases were eluted by passing $10 \mathrm{~mL}$ extraction solvent (Dichloromethane : hexane; 3:1) and fraction was evaporated in a gentle steam of nitrogen. Final volume was made up into $1 \mathrm{ml}$ by $\mathrm{n}$-hexane and injected $1 \mu \mathrm{l}$ in gas liquid chromatograph equipped with an electron capture detector $\left(\mathrm{Ni}^{\mathrm{6}}\right)$.

\section{4- Instrumental and operating conditions}

The analysis of the 18 selected OCPs was carried out by capillary gas chromatography using Shimadzu 2010 (Shimadzu, Kyoto, Japan) chromatograph equipped with an electron capture detector $\left({ }^{83} \mathrm{Ni}\right)$, split/splitless injection port, a DB-5 (5 \% phenyl polysiloxane) fused silica capillary column by $\mathrm{J} \& \mathrm{~W}$ Scientific (30 m x $0.25 \mathrm{~mm}$ i.d., $0.25 \mu \mathrm{m}$ film thickness) and auto-injector model AOC-20i. Helium was used as the carrier gas while nitrogen was used as the make-up gas. The temperature program was as follows: $80^{\circ} \mathrm{C}$ for $1 \mathrm{~min}, 80-218{ }^{\circ} \mathrm{C}$ at $8{ }^{\circ} \mathrm{C} \mathrm{min}-1,218{ }^{\circ} \mathrm{C}$ for $18 \mathrm{~min}$, $218-250{ }^{\circ} \mathrm{C}$ at $4{ }^{\circ} \mathrm{C} \mathrm{min}{ }^{-1}$ and $250{ }^{\circ} \mathrm{C}$ for $10 \mathrm{~min}$. A $1 \mu l$ volume was injected in a splitless mode at $250^{\circ} \mathrm{C}$. The residues of organochlorine pesticides were determined by comparing the peak areas of the samples and the calibration curves of the standards.

\section{Quality Assurance}

For every set of 10 samples, a procedural blank and spiked sample consisting of all reagents was run to check for interference and cross-contamination. The recovery experiment was performed at three concentrations and each concentration was analyzed in triplicate. All residues are expressed as ug/l. minimum, maximum and geometric means were used to express residue levels. Values below detection limits were assigned as a Not-Detectable (ND). The World Health Organization 1993, and European Economic Commission (EEC) 1980, has set allowable residual limit of individual and total concentration in drinking water set at 0.1 and $0.5 \mu \mathrm{g} / 1$ respectively. The method should be able to extract the pesticides from water samples at the guideline levels. Hence the method is validated by spiking the doubled distilled water with $0.5 \mathrm{ppb}$ level of mixture of pesticides of different group, and analysed. The method's efficiency concerning 18 ECDsensitive compounds has been validated and found satisfactory.

\section{RESULTS AND DISCUSSION}

Results of sample analyses are summarized in Tables (2). These analyses were carried out on samples from different localities and various surface waters in Sana'a City.

Table 2. Concentrations of organochlorine pesticides detected in the groundwater samples

\begin{tabular}{|c|c|c|c|c|c|c|c|c|c|c|}
\hline \multirow{2}{*}{$\begin{array}{l}\text { Organochlorine } \\
\text { pesticide }\end{array}$} & \multicolumn{10}{|c|}{ Concentrations $(\mu \mathrm{g} / \mathrm{l})$} \\
\hline & S1 & S2 & S3 & S4 & S5 & S6 & S7 & S8 & S9 & S10 \\
\hline a-HCH & nd & nd & nd & nd & nd & nd & nd & nd & nd & nd \\
\hline b-HCH & nd & nd & nd & nd & nd & nd & nd & nd & nd & nd \\
\hline lindane & nd & nd & nd & nd & nd & nd & nd & nd & nd & nd \\
\hline $\mathrm{d}-\mathrm{HCH}$ & nd & nd & nd & nd & nd & nd & nd & nd & nd & nd \\
\hline Heptachlor & nd & nd & nd & nd & nd & nd & nd & nd & nd & nd \\
\hline aldrin & nd & nd & nd & nd & nd & 0.0002 & nd & nd & nd & nd \\
\hline heptachlor epoxide & nd & nd & nd & nd & nd & nd & nd & nd & nd & nd \\
\hline a-endosulfan & nd & nd & nd & nd & nd & nd & nd & nd & nd & nd \\
\hline 4,4-DDE & nd & nd & nd & nd & nd & nd & nd & nd & nd & nd \\
\hline dieldrin & nd & nd & nd & nd & nd & nd & nd & nd & nd & 0.0007 \\
\hline endrin & nd & nd & nd & nd & nd & nd & nd & nd & nd & nd \\
\hline b-endosulfan & nd & nd & nd & nd & nd & nd & nd & nd & nd & nd \\
\hline 4,4-DDD & nd & nd & nd & nd & nd & nd & nd & nd & nd & nd \\
\hline endrin aldehyde & nd & nd & nd & nd & nd & nd & nd & nd & nd & nd \\
\hline endosulfan sulfate & nd & nd & nd & nd & nd & nd & nd & nd & nd & nd \\
\hline 4,4-DDT & nd & nd & nd & nd & nd & nd & nd & nd & 0.0005 & nd \\
\hline methoxychlor & nd & nd & nd & nd & nd & nd & nd & nd & nd & nd \\
\hline endrin ketone & nd & nd & nd & nd & nd & nd & nd & nd & nd & nd \\
\hline
\end{tabular}

nd: not detected 
Three residues of 18 targeted OCPs (4,4-DDD, 4,4-DDE, 4,4-DDT, a-endosulfan, a-HCH, aldrin, bendosulfan, b- $\mathrm{HCH}, \mathrm{d}-\mathrm{HCH}$, dieldrin, endosulfan sulfate, endrin, endrin aldehyde, endrin ketone, heptachlor, heptachlor epoxide, lindane and methoxychlor) were found in 3 samples only. Among the pesticides analyzed only, aldrin $(0.0002 \mu \mathrm{g} / \mathrm{l})$, dieldrin $(0.0007 \mu \mathrm{g} / \mathrm{l})$ and 4,4-DDT $(0.0005 \mu \mathrm{g} / \mathrm{l})$ were found in the groundwater samples. The mean total concentration of $0.0007 \mu \mathrm{g} / \mathrm{l}$ observed for dieldrin was the highest while mean total concentration of 0.0002 $\mu \mathrm{g} / \mathrm{l}$ observed for ardrin was the lowest. Most of the published research work used the conventional extraction and clean-up methods, in the current work a SPE was used because it is: affordable, convenient, simpler, efficient extraction and less solvent consumption (Albanis and Hela., 1995; Crescenzi et al., 1997; Miliadis 1998; Doong 1999 and David et al., 2011). For all compounds examined, all concentration levels of residues were found to be within WHO Guidline (World Health Organization 1993) and Europen Economic Commission Standards (EEC Council Directive 1980/778/EEC) for drinking water quality. These results demonstrate that there are no existed certain potential health risks to drinking water consumer in Sana'a city. Table (2) showed that only three groundwater sampling areas (Sawan, Al-asbahi and Bany huat) was found to contain pesticide residues. It is well known that aldrin and dieldrin are closely related organochlorines, when aldrin is applied in the field; it is rapidly broken down to dieldrin (Turgut 2003), that is explaining the presence of dieldrin in some sampling areas. Since no information form earlier studies regarding OCPs residue in Yemen, it will be difficult to compare our results. The present results are the first of their kind for Yemen and should serve as background information.

Factors influencing pesticide movement to groundwater include properties of the pesticide, properties of the soil, rainfall and depth of ground water, method and rate of application of pesticide (Buttler et al., 1993). The Organochlorines solubility in water is low; their mobility in soil is generally limited, although it is greater in sandy soil. They tend to be bound in clay soils with limited leaching. It is well known that a high clay content and organic matter content exhibit the high adsorption capacity, it was also noted that the relatively high organic matter content and clay content of soil restricted the leaching of the soil. However, the key factors in determining whether pesticide residues will be leached to groundwater are primarily the mobility of the compound and secondarily its persistence (Foster and Chilton., 1998). There are several reasons for Organochlorine pesticides contamination of groundwater: due to their molecular features (Ahmed et al., 1998); persistent nature and translocation from agricultural land (Matin et al., 1998); the abundant application and or long half-life period in a neutral environment (Tomlin 1994); faults in the well casings allowing surface water into the wells, also there could be large fractures in the bedrock which result in relatively fast flow of groundwater and recharge from the surface (Eitzer and Chevalier., 1999).
The ground water level in Sana'a basin is very deep, most borehole depths in the Tawilah Sandstone aquifer vary from $100-400 \mathrm{~m}$. Depth to water is between $50-150 \mathrm{~m}$ in most boreholes. The thick, unsaturated zone, resulting from deep groundwater levels (100-170 $\mathrm{m}$ below ground level) suggests that groundwater pollution is unlikely. However, the complex geological structure and the presence of rock fractures could reduce the travel time of pollutants through this layer. The use of pesticides and chemical fertilizers in agriculture in Yemen is, however, still at a relatively low level and therefore groundwater contamination from this source is not of major concern at present (Richard et al., 1997).

Ground water quality at Sana'a city wasn't within the concern of the related parties, that is may be due to the absence of well-equipped accredited laboratories in the country. Only two earlier studies were found to describe the quality of groundwater: (Al-Hamdi, 1994) investigated the quality of groundwater in the city of Sana'a, they concluded that no immediate risk was thought to exist for the wellfields. (Al-Eryani et al., 1991) concluded that industrial wastewater in the Sana'a area was not presenting an immediate threat to the quality of the groundwater; their focus was on heavy metals and inorganic pollutants.

\section{CONCLUSION}

This method has been developed for the simultaneous extraction and cleanup of 18 OCPs in groundwater samples. SPE with DCM:hexane technique showed to be viable and reliable method, it also has been shown to be rapid alternative for the quantitative and qualitative analysis of OCPs in groundwater samples. The method is inexpensive simple, precise and reproducible for the analysis of wide range of OCPs pesticides. The proposed method can be applied to the fortified and real groundwater samples contaminated with OCPs at the $\mu \mathrm{g} / \mathrm{l}$ level. We recommend that on-going monitoring be continued to determine the OCPs residue levels and further studies to be carried out to determine the pathways of OCPs contamination in groundwater. The method may serve as a screening protocol for the determination of OCPs in groundwater samples on a routine basis.

\section{ACKNOWLEDGMENT}

The authors would like to appreciate the Deanship of the Faculty of Agriculture of Sana'a University, for the financial support.

\section{REFERENCES}

Adeyemi D, Ukpo G, Anyakora C, and Unyimadu JP, (2008) Organochlorine pesticide residues in fish samples from Lagos Lagoon, Nigeria. Am. J. Environ. Sci. 4(6): 649-653.

Afful S, Anim A, and Serfor-Armah Y (2010) Spectrum of organochlorine pesticide residues in fish samples from the Densu Basin. Res. J. Environ. Earth Sci. 2(3): 133-138.

Ahmad SH, Fujita IW, and Katsuhisa H, (2013) Concentrations of organochlorine pesticides (OCPs) residues in foodstuffs collected from traditional markets in Indonesia. Chemosphere. 90 (5) 1742-1750. 
Ahmed MT, Saad MM, and Mabrouk SS, (1998) Residues of some chlorinated hydrocarbon pesticides in rain water, soil, and ground water, and their influence on some soil microorganisms. Environ Int. 24 665-670.

Albanis TA, and Hela DG, (1995) Multi-residue pesticide analysis in environmental water samples using solidphase extraction discs and gas chromatography with flame thermionic and mass-selective detection. J. Chromatogr. A. 707 283-292.

Al-Eryani M, Ba-issa A, and Al-Shuibi, Y, (1991) Groundwater Pollution in the Sana'a Basin: a Preliminary Appraisal. Environmental Protection Council, Sana'a, Republic of Yemen.

Al-Hamdi M, (1994) Groundwater Pollution due to Municipal Wastewater Disposal. M.Sc. thesis, IHE, Delft, The Netherlands.

Ananda G, and Somashekar RK, (2012) Monitoring of pesticide residues in farmgate samples of vegetables in Karnataka, India. Int. J. Sci. and Nature, I.J.S.N. 3(3): 563-570

Ashok KM, and Aman K, (2013) Organochlorine pesticides in the surface waters from Sharda River Region, Uttar Pradesh-India. The SIJ Transactions on Advances in Space Research \& Earth Exploration (ASREE). 1 1-7.

Aydin, and Yurdin T, (1999) Residues of organochlorine pesticides in water sources of Istanbul. Water Air Soil Pollut. 111 385- 398.

Belta GD, Likata P, Bruzzese A, Naccarri C, Trombetta D, Turco VL, Dugo C, Richetti A, and Naccari F, (2006) Level and congener pattern of PCBs and OCPs residues in blue-fin tuna (Thunnus thynnus) from the straits of Messina (Sicily, Italy). Environ. Int. 32: 705-710.

Bouman H, (2004) South Africa and the Stockholm on persistent organic pollutants. Afr. J. Sci. 100: 323328.

Buttler T, Martinkovic W, and Nesheim ON, (1993) Factors influencing pesticide movement to ground water. Fact Sheet PI-2, Institute of Food and Agricultural Sciences, University of Florida Gainesville.

Cocco P, Blair A, Congia P, Saba G, Flore C, Ecca MR, and Palmas C, (1997) Proportional mortality of dichlorodiphenyl-trichloroethane (DDT) workers: a preliminary report, Arch. Environ. Health 52(4):29930352: 299.

Colborn T, and Smolen MJ, (1996) Epidemiological analysis of persistent organochlorine contaminants in cetaceans. Rev. Environ. Contam. Toxicol. 146: 91172.

Crescenzi AC, Guerreiro O, and Samperi R, (1997) Development of a multi residue method for analyzing pesticide traces in water based on solid-phase extraction and electro spray liquid chromatography mass spectrometry. Environ. Sci. Technol. 31 479-488.

David A, Chimezie A, Grace U, Adeleye A, and Godfred D, (2011) Evaluation of the levels of organochlorine pesticide residues in water samples of Lagos Lagoon using solid phase extraction method. J. Environ. Chem Ecotoxicol. 3(6) 160-166.
David A, Chimezie AG, Adeleye A, and Godfred D, (2011) Evaluation of the levels of organochlorine pesticide residues in water samples of Lagos Lagoon using solid phase extraction method. J. Environ. Chem. Ecotoxicol. 3(6) 160-166.

Davies DL, and Barlow HL, (1995) Can environmental estrogen cause breast cancer? Sci. Am. October. 144147.

Doong R, Lee C, (1999) Determination of organochlorine pesticide residues using solidphase extraction cleanup cartridges. Analyst 124 1287-1289.

DouAbul A, and Al-Shwafi N, (2000) Organochlorine pesticides and PCBs in the Red Sea and Gulf of Aden, Yemen coasts. Yemen J. Sci. 1 (2) 49-60.

Edwards CA, (1987) The environmental impact of pesticides. Parasitis. 86: 309-329.

Eitzer BD, and Chevalier A, (1999) Landscape care pesticide residues in residential drinking water wells. Bull. Enviorn. Contam. Toxicol. 62 420-427.

Ennacer S, Gandaoura N, and Driss R, (2008) Distribution of polychlorinated biphenyls and organochlorine pesticides in human breast milk from various locations in Tunisia: levels of contamination, influencing factor and infant risk assessment. Environ. Res. 108 86-93.

European Economic Commission (EEC) Council Directive 80/778/EEC (1980), Official Journal of European Communities, Vol. 229, P.11.

Farshid K, Amir HS, Rokhsareh M, and Hamid NA, (2012) Determination of organochlorine pesticide residues in water, sediments and fish from Lake Parishan, Iran. World J. Fish and Marine Sci., 4 (2) 150-154.

Farshid K, Amir HS, Rokhsareh M, and Hamid NA, (2012) Determination of organochlorine pesticide residues in water, sediments and fish from lake Parishan, Iran. World J. Fish and Marine Sci. 4 (2): 150-154.

Fatoki OS, and Awofolu RO, (2003) Methods for selective determination of persistent organochlorine pesticide residues in water and sediments by capillary gas chromatography and electron-capture detection. J. Chromatogr. A 983 225-236.

Fleming L, Mann JB, Briggle T, and Sanchez-Ramos JR (1994) Parkinson disease and brain levels of organochlorine pesticides. Ann. Neurol. 36: 100-103.

Foster SS, and Chilton PJ, (1998) The effects of agricultural cultivation on groundwater. pp. 15-43.

Garabrant DH, Held J, Langholz B, Peter JM, and Mark TM, (1992) DDT and related compounds and risk of pancreatic cancer. J. Natl. Cancer Inst. 84: 764-771.

Getenga ZM, Kengara FO, and Wandiga SO, (2004) Determination of organochlorine pesticides in soil and water from river Nyando drainage system within Lake Victoria Basin, Kenya. Bull. Environ. Contam. Toxicol. 72(2): 335-342.

Hajslova J, and Zrostlikova J, (2003) Matrix effects in ultratrace analysis of pesticide residues in food and biotic matrices. J. Chromatogr. A 1000 181-197. 
Hileman E, Chem. Eng. (1994) Environmental estrogens linked to reproductive abnormalities, cancer. $\mathrm{C}$ and EN, 31 January, 19-23.

Ize Iyamu OK, Abia IO, and Egwakhide PA, (2007) Concentration of residues from organochlorine pesticides in water and fish from some rivers in Edo state, Nigeria. Int. J. Phys. Sci. 2: 9.

Ize-Iyamu OK, Asia IO, and Egwakhide PA, (2007) Concentrations of residues from organochlorine pesticide in water and fish from some rivers in Edo State Nigeria, Int. J. Phy. Sci. 2 (9) 237-241.

Kolpin DW, Thurman EW, and Lingart SM, (1998) The environmental occurrence of herbicides: the importance of degradates in ground water. Bull. Environ. Contam. Toxicol. 35: 385-90.

Matin MA, Malek MA, Amin MR, Rahman S, Khatoon J, and Rahman M, (1998) Organochlorine insecticide residues in surface and underground water from different regions of Bangladesh. Agri. Ecosys. Environ. 69 11-15.

Miliadis GE, (1998) Analysis of pesticide residues in water samples by gas capillary chromatography. Bull. Environ. Contam. Toxicol. 61 255-260.

Narasimha RK, Aruna M, and Satyanarayana S, (2012) Determination of pesticide residues by multi residues method in water of Hussansagar and Mir Alam Lakes of Hyderabad, India. J. Chem. Bio. Phy. Sci. 2 (1) $505-510$.

Okonkwo JO, Kampita L, and Chingakule DD (1999) Organochlorine insecticide residues in human milk: A study of lactating mothers in Siphofaneni, Swaziland. Bull. Environ. Contam. Toxicol. 63 243247.

Prudente, M., Ichihashi, H., Kan-atireklap, S., Watanabe, I., Tanabe, S., (1999). Butyltins, organochlorines and metal levels in green mussel, Perna viridis L. from the coastal waters of the Philippines. Fisheries Science 65, 441-447.

Qin YY, Leung CK, Leung AO, Zheng JS, and Wong MH, (2011) Persistent organic pollutants in food items collected in Hong Kong. Chemosphere. 82 13291336.
Republic of Yemen, Ministry of Water and Environment MWE (2003), Environment Protection Authority (EPA), Yemen's National Programme of Action for the Protection of the Marine Environment from Land-Based Activities.

Richard H, Ivanildo H, Spon F, and Mohamed Al-H, (1997) Water Pollution Control - A Guide to the Use of Water Quality Management, United Nations Environment Programme, the Water Supply \& Sanitation Collaborative Council and the World Health Organization Case Study XIII* - Sana'a, Yemen.

Safina M, John WG, Phillip OR, and Christopher MA, (2011) Organochlorine and organophosphorus pesticide residues in water and sediment from Yala/Nzoia River within Lake Victoria Basin, Kenya. J. of Eco. Nat. Environ. 3(12) 392-399.

Tanabe, S., A. Subramanian, A. Ramesh, P.L. Kumaran, N. Miyazaki and R. Tatsukawa, (1993) Persistent organochlorine residues in dolphins from the bay of Bengal, South India. Mar. Pollut. Bull., 26: 311-316.

Tomlin C, (1994) The Pesticide Manual, A World Compendium. BCPC, (10th edn.).

Turgut C, (2003) The contamination with organochlorine pesticides and heavy metals in surface water in Küçük Menderes River in Turkey, 2002-2003. Environ. Int. 29 29-32.

William J, Tagoe L, Drechsel P, Kelderman P, Gijzen H, and Nyarko E (2008) Accumulation of persistence organochlorine contaminants in milk and serum of farmers from Ghana. Environ. Res. 106 17-26.

William J, Tagoe L, Drechsel P, Kelderman P, Gijzen H, and Nyarko E, (2008) Accumulation of persistence organochlorine contaminants in milk and serum of farmers from Ghana. Environ. Res. 106: 17-26.

World Health Organization (1993), Guidelines for drinking water quality (2nd ed., Vol. 1.). Recommendations, Geneva, Switzerland.

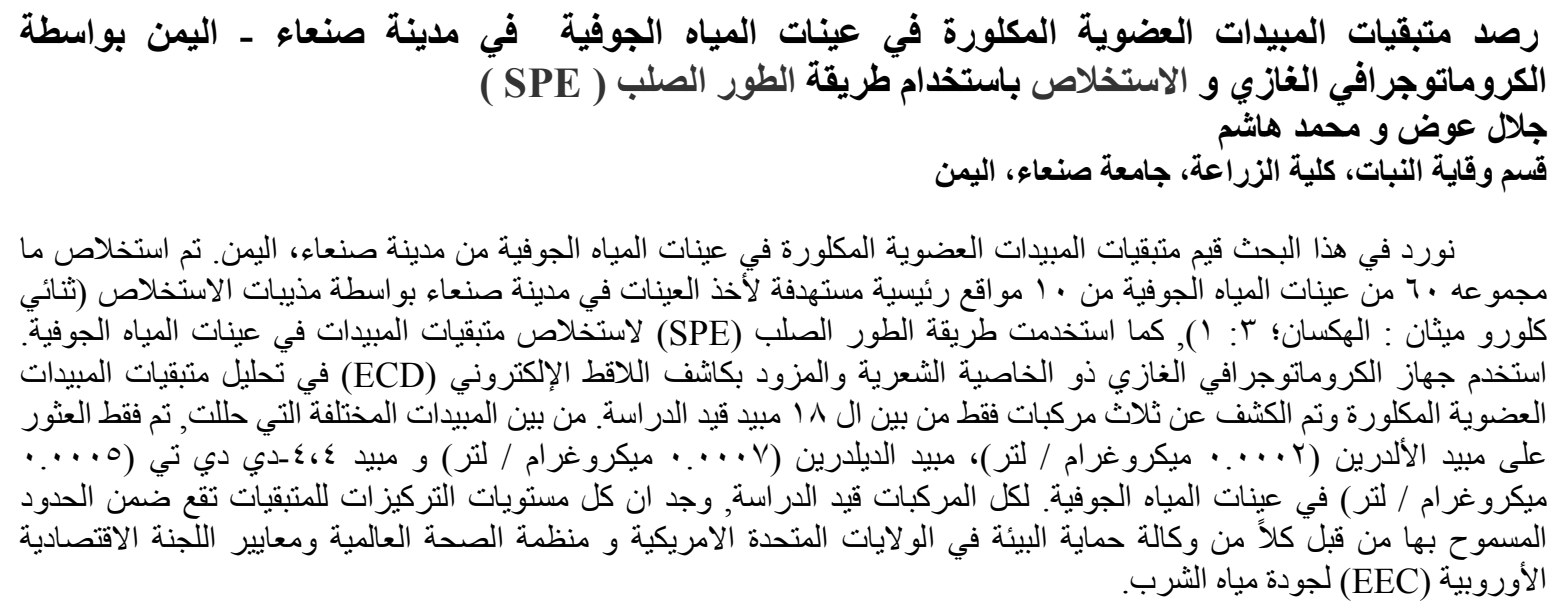

